\title{
乳房撮影システムにおける特性曲線の作成（距離法）II フィルム法と線量測定法による検討
}

Sensitometry for Mammographic System : 2st Report

川椅医科大学附属病院中央放射線部

川䗁医療短期大学放射線技術科
○末森 慎治、真田 秦三、弯藤 尚之、石井 幸志 (Shinji Suemori) (Taizou Sanada) (Naoyuki Saitou) (Koushi Ishii) 天野 貫司、荒尾 信一、北山 彰、山下一也 (Takashi Amano) (shinichi Arao) (Akira Kitayama) (Kazuya Yamashita)

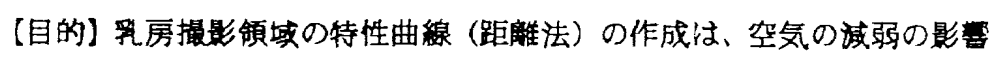
を受けるために技術的に困踓とされてきた。今回我々は、実効エネルギー

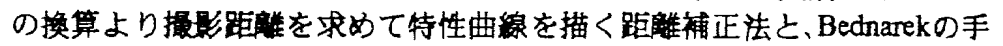

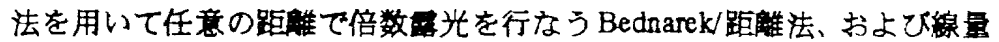
計を用いて相対線量檤と写真漟度の関係より求めた線量計法の3 種類の手 法を用い特性曲線を作成し、その各手法の模討を行なつた。

（方法１）距噰補正法は、撮影管電圧 $25 \mathrm{kV}$ で半価層より実効エネル

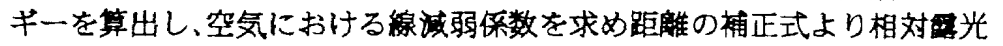
距離を算出し Min-R/MRM,MR2000/MR2000 (Kodak) を用い、最長串光距 離 $350 \mathrm{~cm}$ 最短露光距離 $40.9 \mathrm{~cm}$ まで露光を行ない特性曲線を得た。(図 1 下段)

2）Bednarek/距離法は、Bootstrap 法を発展した考えで、最長露光距離 $350 \mathrm{~cm}$ を基準にし標準照射 E1、2 倍照射（mAs 值 2 倍）を $2 \mathrm{E} 1$ とし同一 距﨎にて露光を行ない、次に任意に距隻を移動し同じようにE2、2E2で

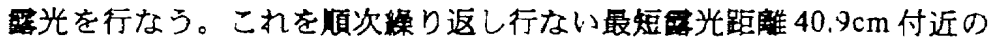
En、2En まで行ない Bednarek の手法を用い特性曲線を得た。（罒 1 上段） また、標準照射に対する2倍照射の正確な倍数比を求めるために線量計 (RAMTEC1000,PTW-FREIBURG,TYPE-N23344-664) を用い、得た倍数比 の対数を比㩆光量間隔（倍数雷光補正）として用いた。

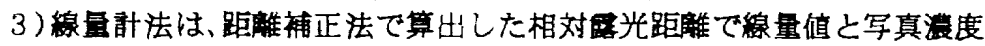
值を用い特性曲線を描いた。

【結果および考宗】図 2 および四 3 にMin-R/MRM とMR2000MR2000の 特性曲線とグラジェント曲線を示す。また、表 1 には 3 種類の手法を用い て得た特性曲線の特性值を示す。いづれの手法とも特性曲線の形状および グラジエント曲線の形状は良く一致した。3種類の手法ことの特性犆を Bednarek/距離法を基準にして比較すると Min-R/MRMで平均グラジェン トが最大 $1.8 \%$ の違いを認め最大階調度で $3 \%$ の違いを認めた。また、 MR2000/MR2000では平均グラジエントが最大でも $1.1 \%$ 、最大階部度で 2.4\%の違いを認めるにすぎなかった。相対感度は、Min-R/MRMを基準に した時に MR2000/MR2000で151\%になつた。(表 1)

いずれの手法を用いても特性曲線作成に違いは証められなかったが各手法 共に問題点がある。距離補正法では、用いる撮影管電圧が变化すればその 都度線量計を用い半価居から実効エネルギ一を求め、空気における線減弱 係数より距離の補正式で相対露光距㒕を求めなければならず、このため計 算過程が煩雑になりやすい。線量計法においては、相対線量と写真淔度が わかれば㧹影路離の决定を行なわなくても特性曲線が得られると考える

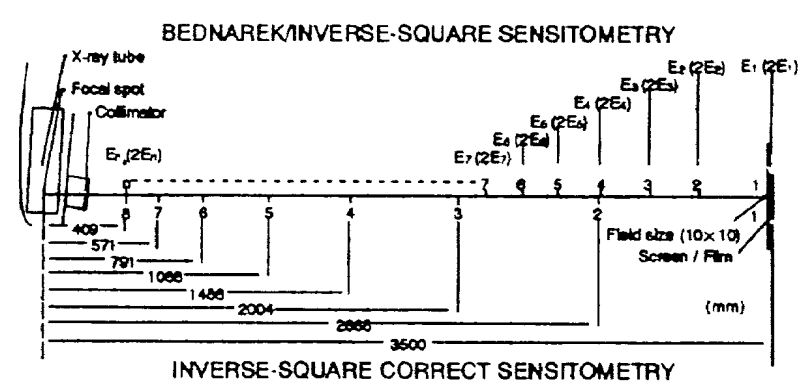

図 1 使用した撮影距離
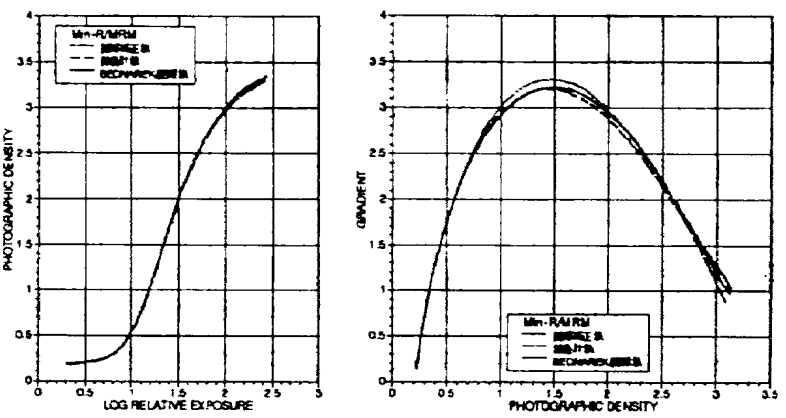

因 2 Min-R/MRMの特性曲線とグラジェント曲線
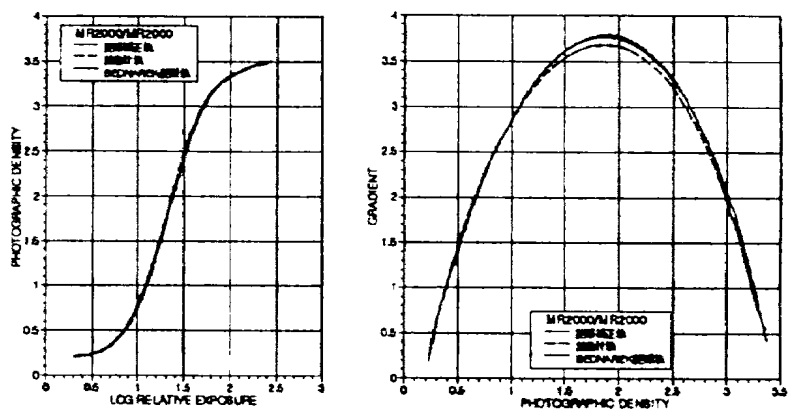

図 3 MR2000/MR2000の特性曲線とグラジェント 曲線

が、缐量計の安定性が必要である事が条件となる。また、写真漕度が必要なため增感紙/フィルムを用い線量計で睦定を行なった撮 影距離にて再度実偀を行なわなくてはならない。Bednarek/距離法においては、増感紙/フィルム系があれば特別な器具を必要とし ないため距離補正法や線量計法の様な手間がなく、どの施設においても乳房撮影領域の特性曲線が得られると考える。

〔まとめ】距離補正法、線量計法およびBednarek距離法ともに特性曲線の形状などに大きな違いは䜀められなかった。また、特性 曲線を求める手技においては、Bednarek/距噰法を用いる事で简単にその特性を得る事ができるが、湲度洞定点を多く必要とするた め今後の課題として榙郡が必要である。

\begin{tabular}{lcccccc}
\hline METHOD & \multicolumn{2}{c}{ INVERSE-SQUARE(CORRECT) } & \multicolumn{2}{c}{ BEDNAREKINVERSE-SQUARE } & \multicolumn{2}{c}{ DOSEMETER } \\
\hline SCREEN/FILM & Min-R/MRM & MR2000/MR2000 & Min-R/MRM & MR2000/MR2000 & Min-R/MRM & MR2000/MR2000 \\
\hline AVE.GRADIENT & 2.8 & 2.85 & 2.75 & 2.82 & 2.74 & 2.83 \\
& $101.8(\%)$ & $101.1(\%)$ & $100.0(\%)$ & $100.0(\%)$ & $99.6(\%)$ & $100.4(\%)$ \\
GRADIENT(MAX) & 3.31 & 3.83 & 3.28 & 3.77 & 3.18 & 3.68 \\
& $100.9(\%)$ & $101.6(\%)$ & $100.0(\%)$ & $100.0(\%)$ & $97.0(\%)$ & $97.6(\%)$ \\
\hline
\end{tabular}

表 1 三手法より求めた特性值 